\title{
Çalışma Yaşam Kalitesinin İşten Ayrılma Niyetine Etkisinde Örgütsel Sinizmin Aracılık Rolü*
}

\section{The Mediating Role of Organizational Cynicism in the Effect of Quality of Work Life on Turnover Intention}

\author{
Mustafa Yildırım, ${ }^{\text {a }}$ Sefa Ceyhan ${ }^{\text {b,*** }}$ \\ ${ }^{a}$ Dr. Öğr. Üyesi, Alanya Alaaddin Keykubat Üniversitesi, İktisadi ve İdari Bilimler Fakültesi, İşletme Bölümü, 07425, Antalya/Türkiye. \\ ORCID: 0000-0003-4471-1333 \\ ${ }^{\text {b }}$ Burdur Mehmet Akif Ersoy Üniversitesi, İktisadi ve İdari Bilimler Fakültesi, İşletme Bölümü, 15030, Burdur/Türkiye. \\ ORCID: 0000-0002-3788-0756
}

\section{MAKALE BİLGİSİ \\ Makale Geçmişi: \\ Başvuru tarihi: 07 Kasım 2019 \\ Düzeltme tarihi: 08 Mart 2020 \\ Kabul tarihi: 24 Mart 2020}

\section{Anahtar Kelimeler:}

İşten Ayrılma Niyeti

Çalışma Yaşam Kalitesi

Örgütsel Sinizm

Otel İşletmeleri
ÖZ

$\mathrm{Bu}$ araştırma, çalışma yaşam kalitesinin işten ayrılma niyeti üzerindeki etkisinde örgütsel sinizmin aracı rolünü belirlemek amacıyla gerçekleştirilmiştir. Bu amaç doğrultusunda Antalya ilinde faaliyet gösteren beş yıldızlı otel işletmelerinde çalışan işgörenler üzerinde alan araştırması yapılmıştır. Alan araştırmasında yüz yüze anket yöntemi ile 223 işgörenden veri toplanmıștır. Söz konusu veriler üzerinde gerçekleştirilen analiz sonuçlarına göre işgörenlerin çalışma yaşam kalitesi azaldıkça örgütsel sinizm ve işten ayrılma niyetinin arttığı yönünde bulguya ulaşılmıştır. Ayrıca çalışma yaşam kalitesinin işten ayrılma niyeti üzerindeki etkisinde örgütsel sinizmin tam aracı role sahip olduğu da araştırma sonuçları arasında yer almaktadır. Elde edilen bu sonuçlar, çalışma yaşam kalitesine yönelik olumsuz algıların örgütsel sinizmi desteklediğini ve işten ayrılma niyetine sebep olduğunu ifade etmektedir.

\section{ARTICLE INFO}

Article history:

Received 07 November 2020

Received in revised form 08 March 2020

Accepted 24 March 2020

\section{Keywords:}

Turnover Intention

Quality of Work Life

Organizational Cynicism

Hotel Organizations

\section{A B S T R AC T}

This study was conducted to determine the mediating role of organizational cynicism in the effect of quality of work life on turnover intention. For this purpose, a field study was carried out on the employees working in five-star hotels in Antalya. Data were collected by face to face survey method from 223 employees. According to the results of the analysis conducted on these data, it was found that organizational cynicism and turnover intention will increase as employees' quality of work life decreases. In addition, it has been found that organizational cynicism has a full mediating role in the effect of work quality of life on turnover intention. These results indicate that negative perceptions of quality of work life support organizational cynicism and cause turnover intention.

\section{Giriş}

Otel işletmelerinde çalışan bireylerin örgütün başarısı ve sunulan hizmetin kalitesi açısından diğer işletmelere görece daha önemli olduğu ifade edilebilir (Yin-Fah vd., 2010; Su, 2014; Zopiatis vd., 2014). Bu sebeple otel işletmelerinde çalışan bireylerin işten ayrılma niyetinin (İAN) azaltılması amacıyla çalışmalar yapılması ve öneriler sunulması gerekmektedir (Avcı ve Küçükusta, 2009). İAN, çalışanın yakın gelecekte işine kendi isteği ile son verme düşüncesinden oluşmaktadır (Bouckenooghe vd., 2013). Buna yol açan etkenlerden birisi de düşük çalışma yaşam kalitesidir. Çalışma yaşam kalitesi (ÇYK), düşük olan bir işyerinde çalışan bireylerin etkin ve verimli olmasının

\footnotetext{
*Bu araştırma, 1-2 Kasım 2019 tarihlerinde Burdur'da düzenlenen 7. Ulusal Örgütsel Davranış Kongresi’nde, “Çalışma Yaşam Kalitesinin İşten Ayrılma Niyetine Etkisinde Örgütsel Sinizmin Aracılık Rolü” başlıklı genişletilmiş özet bildiri olarak sunulmuştur.

** Sorumlu yazar/Corresponding author

e-posta: ceyhansefa@ hotmail.com
} 
oldukça zor olduğu ifade edilebilir. Bu durum hem örgütsel hem de bireysel düzeyde başarısızlık ile sonuçlanabilmektedir. $\mathrm{Bu}$ başarısızlığın engellenmesinin örgütlerde ÇYK'nin arttırılması ve İAN'nin düşürülmesi ile mümkün olacağı çıkarımında bulunulabilir. Ancak bu durumun sağlanmasında örgütün performansını olumsuz yönde etkileyen ve örgütsel sinizm gibi tutumların (Mirvis ve Kanter, 1991: 53) önemi de yadsınmamalıdır. Dolayısıyla bu araştırmada; ÇYK'nin İAN üzerindeki etkisi ve bu olası etkide, örgütsel sinizmin aracı rolünün belirlenmesi amaçlanmıştır.

\section{Kavramsal Çerçeve}

Çalışma yaşam kalitesi (ÇYK), örgüt içi çalışma koşullarının belirlenmesi ya da çalışan tatminini olarak ifade edilmektedir (Martel ve Dupis, 2006: 334). Bir başka deyişle, çalışanların çalışma yaşamıyla ilgili kararlarda fikir belirtmesine imkân tanınmasıdır (Walton, 1975: 13). Bu imkân doğrultusunda ÇYK'nin işgörenlerin çalışma ortamına yönelik tepkilerini ifade eden bir kavram olduğu öne sürülebilir (Turan, 2014: 12). Söz konusu çalışma ortamı, kimi araştırmacılara göre bireysel yaşam doyumunu olumlu ya da olumsuz etkilerken (Judge ve Watanabe, 1994: 102), kimi araştırmacılara göre bireysel yaşam doyumu, çalışma ortamından doğrudan etkilenmektedir (Elizur, 1991: 313; George ve Brief, 1990: 357). Bu etki; yapılan işin niteliği, ücret, çalışma şartları ve çalışılan ortam, teknoloji, endüstriyel ilişkiler, iş tatmini ve motivasyon, işe katılım, sosyal adalet, iş güvencesi ve sürekli eğitim gibi faktörlerden kaynaklanmaktadır (Üstündağ, 1999: 93). ÇYK ile ilgili detaylı araştırmalar yapan Walton'a (1975) göre söz konusu faktörler sekiz alt boyuta ayrılmaktadır. $\mathrm{Bu}$ boyutlar sirasiyla; sosyal etkileșim, demokratik ortam, sosyal destek, sosyal bütünleşme, sürekli gelişim, bireysel kapasitenin kullanılması, sağlıklı ve güvenli çalışma koşulları ve yeterli ve adil ücretlendirme şeklindedir (Sojka, 2014: 286). Sosyal etkileşim boyutunda, çalışanların birbirleri ile olan etkileşimini arttırmak amaçlanmaktadır. $\mathrm{Bu}$ etkileşim sağlandığında çalışan örgüt içerisinde yalnızlık algısına kapılmayacak ve kendisini örgütün bir parçası olarak hissedecektir (Akman ve Akman, 2017: 1500). Örgüt içerisinde demokratik ortamın sağlanmasının ise çalışanların fikir ve görüşlerini açıkça sunmasını mümkün k1lacağ1 düşünülmektedir (Lokanadha ve Mohan, 2011: 834). Bu imkân doğrultusunda elde edilen sosyal destek, çalışanlar arasında çatışma çıkmasını engelleyerek huzurlu bir çalışma ortamı oluşmasına olanak tanımaktadır. ÇYK'nin bir başka boyutu olan sosyal bütünleşme, çalışan ve yönetici arasında ortak çalışma esasına dayalı olarak sorunların çözümlenmesinde her bireyin aktif katılım sağlaması kapsamında değerlendirilmektedir (Rose vd., 2006: 62).

Çalışanın örgüt içinde katılım sağlaması kapsamında değerlendirilen bir diğer boyut ise sürekli gelişimdir. $\mathrm{Bu}$ boyutta bireyler, örgüte fayda sağlamak amacıyla deneyim ve yetenekleri doğrultusunda hareket etmektedirler (Markham, 2009: 36). Böylelikle çalışanların bireysel kapasitesi kullanılarak yetenek ve deneyimleri arttırılmaktadır. Çalışılan ortamın sağlıklı ve güvenli olması ise bireylerin kendini güvende hissetmelerine sebep olmaktadır (Cabrera ve Cabrera, 2005: 720). Son olarak örgüt içerisindeki yeterli ve adil ücretlendirme çalışanların sunmuş oldukları hizmet ya da ürün karşılığında tatmin edici ücret almasını kapsamaktadır (Morton, 1977: 64). Buradan hareketle ÇYK'nin tüm bu faktörleri içeren kapsamlı bir yapıya sahip olduğu ve örgüt içerisinde uygulanması gereken kuralları belirlediği ifade edilebilir. $\mathrm{Bu}$ kurallar içerisinde örgütlerin devamlılık esasına bağlı olarak demokratik ortamda işleyişinin sağlanması, sağlıklı bir çalışma ortamı kapsamında gelişime açık ve güvenilir ilişkilerin oluşturulması sıralanabilir (Zengin 2018: 75; Alan, 2012: 16). Bu noktada ÇYK'nin yüksek olması gerek bireysel gerek örgütsel bir takım olumlu sonuçlar doğurmaktadır. Bu sonuç otel işletmeleri üzerine yapılan bir çalışmada da desteklenmektedir. Örneğin, Pelit ve Gökçe (2019) tarafından gerçekleştirilen araştırmada, yöneticiye duyulan güven arttıkça ÇYK'nin de arttığı ifade edilmektedir. Şehir otellerinde yapılan bir başka çalışmada ise ÇYK'nin sayfiye bölgelerinde çalışan işgörenlere göre daha yüksek olduğu bu durumun şehir otellerinde hak ve kuralların düzenli bir örgüt iklimi içerisinde yer alması yoluyla gerçekleştiği belirtilmektedir (Tuncer ve Yeşiltaş, 2013: 57). Dolayısıyla, ÇYK'nin niteliği hem işgörenlerin örgütsel benliklerini oluşturmakta hem de mesleki performans düzeyleri ile mesleki girişimciliklerini arttırmaktadır. Öte yandan tükenmişliğin önlenmesi, stresli yaşam şartları ve sorunlarla başa çıkma yeteneği kazandırması ve kişinin sahip olduğu imkanlardan tatmin olmasını sağlaması da olumlu örgütsel sonuçlar arasında siralanabilmektedir (Kheirandish, 2009; Pfeffer, 2004; Waitayangkook, 2003; Donalson, 2000; Veenhoven, 1996). Ancak ÇYK'nin düşük olması her iki aktör için de örgütsel bağlılığın azalması, performansın azalması ve iş stresinin artması gibi birtakım olumsuzluklara yol açabilmektedir (Donalson, 2000; Swamy ve Nanjundeswaraswamy, 2015). Bu olumsuzluklardan biri de örgütsel sinizmdir.

Örgütsel sinizm, bireyin içinde bulunduğu örgüte karş1 tutum ve davranışlarını içeren olumsuz tepkiler bütünüdür (Dean vd., 1998: 345). Dürüstlükten yoksun olan örgüt algısı genellikle; ahlak, adalet ve güven ile ilgili temel gerekliliklerin göz ardı edilmesinden kaynaklanmaktadır (Johnson ve O'Leary-Kelly, 2003: 629). Örgütsel sinizm kavramının kuramsal çerçevesini; beklenti kuramı, atfetme kuramı ve sosyal değişim kuramı oluşturmaktadır (Akman, 2013; Eaton, 2000; James, 2005). Vroom (1964) tarafindan geliştirilen beklenti kuramına göre birey, tutum ve davranışlarını sadece bireysel ihtiyaçlar doğrultusunda değil, aynı zamanda bu davranışların bir sonuca ulaşması yönünde beklenti içerisindedir. $\mathrm{Bu}$ bağlamda beklenti kuramının, örgüt içi kişisel beklentileri ile ilgili olduğu söylenebilmektedir (Fishbein ve Ajzen, 1977: 902; Görmen, 2012: 96). Atfetme kuramı ise, insan eylemlerinin geniş bir alanını, ürün ve sürecini, tutum ve davranışlarını kapsayan çok yönlü neden ve çıkarımlar üzerine kuruludur. Blau (1964) tarafindan geliştirilen sosyal değişim kuramı, bireylerin ihtiyaçlarını tatmin edebilmek için kişiler arası ilişkilerin gerekliliğini ifade etmektedir (Homans, 1961; Cropanzano ve Mitchell 2005; Emerson, 1976).

Örgütsel sinizmin ortaya çıkması üç boyutta gerçekleşmektedir. Bu boyutlardan ilki, örgüt ile ilgili kimi inanışların bireyde meydana gelmesi ile başlayan bilişsel boyuttur. Bu boyut, işgörende; öfke, kıskanma, kınama ve hor görme gibi negatif duygularla meydana gelir ve içinde bulunulan örgütün dürüstlükten yoksun olduğu inancını temsil eder (Dean vd., 1998: 345). Örgütsel sinizmin ikinci 
boyutunu oluşturan duygusal boyut, işgörende oluşmuş inançların hislere dönüşmüş halini ifade etmektedir. Duygusal boyut içerisindeki bireyler içinde bulundukları örgüte karş1 nefret, gerginlik, umutsuzluk ve hatta utanç gibi hisler beslemektedirler (Dean vd., 1998: 346). Örgütsel sinizmin son boyutu ise davranışsal boyuttur. Bu boyutta işgörenler örgüt içi şikâyet kaynaklı mutsuz davranışlar, eleştiri içerikli sözlü olmayan yüz ifadeleri ve alaycı tavırlar sergileyebilmektedir. Bu tür sinik ve sözlü olmayan davranışlara işgörenler arası anlamlı bakışlar, kötümser gülümseyişler örnek verilebilmektedir (Brandes ve Das, 2006: 240).

Söz konusu boyutların yanı sıra örgütsel sinizmin bireysel ve örgütsel sonuçları da bulunmaktadır. Örneğin; memnuniyetsizlik, örgütsel sadakatsizlik, işten ayrılma, yabancılaşma gibi faktörler örgütsel sinizmin örgüte yönelik olumsuz sonuçlarından bazılarını oluşturmaktadır (Abraham, 2000; Andersson ve Bateman, 1997; Eaton, 2000; James, 2005; Naus, 2007). Söz konusu sonuçlar arasında yer alan işe yabancılaşma algısına yönelik yapılan bir araştırma bu durumu doğrulamaktadır. Otel işletmelerindeki örgütsel sinizm ve işe yabancılaşma arasındaki ilişkiye yönelik olarak gerçekleştirilen araştırmada; işgörenlerin işe yabancılaşma düzeylerinin örgütsel sinizmin bilişsel, duyuşsal ve davranışsal boyutları arasında anlamlı ilişki olduğu, örgütsel sinizm algısı arttıkça işe yabancılaşmanın da artış gösterdiği tespit edilmiştir (Özer ve Güllüce, 2019). Olumsuz örgütsel sonuçlara yönelik bir başka örnek ise, Mert ve Yılmaz (2019) tarafindan gerçekleştirilen örgütsel sinizmin motivasyon ve performans üzerindeki etkisine ilişkin çalışmadır. Söz konusu araştırmada, otel çalışanlarının örgütsel sinizm algısı arttıkça motivasyon ve performansın düştüğü sonucuna ulaşılmıştır. Örgütsel sinizm bireysel düzeyde ise, sinik işgörenler gerektiği durumlarda yönetime ve liderlere karşı meydan okuyucu tutumlar ya da aşağılayıcı davranışlar ile kasıtlı olarak kişi ya da örgüte ait bir mala zarar verme eyleminde bulunabilmektedirler (Mishra ve Spreitzer, 1998; Anderson ve Bateman, 1997; Dean vd., 1998). Bu noktada örgütsel sinizmin öncüllerinden birinin de ÇYK olduğunu söylemek mümkündür. Çünkü yazılı/yazısız, açık/örtük beklentileri karşılanmayan bireylerin çalışma yaşam kalitesine yönelik değerlendirmeleri olumsuz olacak ve karşılanmayan beklentiler zamanla örgüte; kızgınlık, eleştiri, alay, şüphe, güvensizlik gibi sinik tutumların gelişmesine zemin hazırlayabilecektir. Bu kapsamda araştırmanın ilk hipotezi şu şekilde oluşturulmuştur:

\section{H1. Çalışma yaşam kalitesi örgütsel sinizm üzerinde negatif etkiye sahiptir.}

ÇYK'nin düşük olmasının yol açacağı durumlardan birinin de işten ayrılma niyeti olduğu düşünülmektedir. İşten ayrılma niyeti (İAN), kişinin çalışmakta olduğu iş yerinden bilinçli ve planlı olarak ayrılmaya karar vermesi ile bu kararını sürekli düşünmesi anlamına gelmektedir (Rusbult vd., 1988: 601; Tett ve Meyer, 1993: 262). Çalışanlar, kendilerini başarılı olarak algıladıklarında işten ayrılma düşüncesi taşımamakta, aksi halde örgüte bağlılıkları azalarak yeni alternatifler arama yolunu tercih etmektedirler (Hardy, 1987: 119). Bu sebeple İAN'nin çalışanların örgüt içinde sergilemiş oldukları tutum ve davranışlarının anlaşılmasında önemli bir etken olduğunu ifade etmek mümkündür (Jung ve Kim, 2012). İAN'nin oluşmasında; aşırı iş yükü, rol çatışması ve rol belirsizliği, çalışan lehine olmayan insan kaynakları uygulamaları, güvenli olmayan çalışma ortamı, iş tatminsizliği ve çalışanlar arası çatışma gibi faktörlerin etkili olduğu bilinmektedir (Pare ve Tremblay, 2000: 14; Kim, 2014: 57). Steel ve Ovalle (1984) tarafından gerçekleştirilen bir araştırmada; İAN ile personel devir hızı arasında anlamlı ilişki olduğu tespit edilmiştir. Öte yandan Cotton ve Tuttle (1986) tarafindan gerçekleştirilen bir başka araştırmada İAN' ne etki eden faktörler; dışsal, kişisel ve iş ile ilgili faktörler olmak üzere üç başlık altında değerlendirilmektedir. Bu faktörlerden ilki olan dışsal faktörler; çalışanların algılama biçimlerini, işsizlik oranlarını ve tekrar işe başlamada yeni örgüte uyum sağlama koşullarını dikkate alırken, kişisel faktörler; çalışanın yaşı, cinsiyeti, eğitim düzeyi, medeni durumu ve çalışma yılı gibi bireysel etkenler üzerinde yoğunlaşmaktadır. İş ile ilgili faktörler ise çalışanın işten ayrılması sonucu yerine yeni çalışan istihdam edilmesi, işin aksaması ve çalışanın eğitilmesi olarak sıralanabilmektedir (Avcı ve Küçükusta, 2009: 37; Tuna ve Yeşiltaş, 2014: 108). $\mathrm{Bu}$ sebeplerden dolayı çalışanların hem örgütsel düzeyde hem de bireysel düzeyde değerli olduğunun hissettirilmesi, onların işten ayrılmayı düşünmesini sağlayacak etkenlerin önlemesi için İAN'nin anlaşılması ve kontrol edilmesi önem taşımaktadır (Mayfield ve Mayfield, 2007: 51). Bu anlaşılma ve kontrol sağlandığında, çalışanlar yeni iş arayışına girmeyecek dolayısıyla örgüt; seçme değerlendirme, eğitme ve adapte etme gibi fazladan maliyete katlanmamış olacaktır (Yücel ve Demirel, 2013: 164).

Şu hâlde örgütlerin, İAN'nin gelişim süreci ve İAN düşüncesinin neden olduğu olumsuz faktörleri tespit etmesi gerekmektedir. $\mathrm{Bu}$ faktörler tespit edildiğinde İAN'nin ortadan kaldırılması amacıyla nelerin yapılması gerekenler belirlenerek örgüt içerisinde oluşması muhtemel sorunlar engellenmiş olacaktır (Çiftçi vd., 2015: 998). İşten ayrılma niyetine yol açan durum ve süreçler incelendiğinde bu durum ve süreçlerin ÇYK'nin düşük, örgütsel sinizmin yüksek olması ile ilgili olduğu görülmektedir. Öyle ki karşılanmayan beklentiler ve buna karşı üretilen bireysel tepki tutumları, zamanla İAN'nin ortaya çıkmasına ve güçlenmesine yol açabilmektedir (Donalson, 2000; Feizi ve Alipour, 2013). Bu noktada araştırmanın ikinci ve üçüncü hipotezi şu şekilde belirlenmiştir:

\section{H2. Çalışma yaşam kalitesi işten ayrılma niyeti üzerinde negatif etkiye sahiptir,}

H3. Örgütsel sinizm işten ayrlma niyeti üzerinde pozitif etkiye sahiptir.

Bireylerin işten ayrılma niyeti, işyerine atfettikleri beklentilerin karşılanmaması halinde hemen ortaya çıkan bir tutum olmakla birlikte zamanla, gelişen ve güçlü hale gelen bir durumla ilgilidir. Dolayısıyla çalışma yaşam kalitesine dair algıların olumsuz olması öncelikle sinik tutumların ortaya çıkmasına ve bunların yerleşik hale gelmesine yol açmaktadır. Bir bakıma İAN öncesi örgütsel iklimi etkileyen tutumlar ortaya çıkmakta ve zamanla bu tutumlar işten ayrılma niyetine evrilmektedir. Diğer bir deyişle işten ayrılma niyetinin öncül nedeni ÇYK'nin görece düşük olmasıdır ayrıca bu düşüklük öncelikle sinik tutumlara yol açmakta ve sonrasında işten ayrılma niyetiyle sonuçlanmaktadır (Sim ve Choi, 2017). Bu kapsamda araştırmanın son hipotezi şu şekilde belirlenmiştir: 
H4. Calışma yaşam kalitesinin ișten ayrlma niyeti üzerindeki etkisinde örgütsel sinizmin aracılık rolü vardır.

\section{Yöntem ve Uygulama}

\subsection{Araştırmanın Evren ve Örneklemi}

$\mathrm{Bu}$ araştırma, amacı ve hipotezleri bağlamında nicel araştırma tasarımlarından olan nedensel ilişki deseni (Erdoğan, 2007) çerçevesinde yürütülmüştür. Saha çalışması Antalya ilinde faaliyet gösteren beş yıldızlı otel işletmelerinde çalışan işgörenler üzerinde gerçekleştirilmiştir. Araştırma evreni olarak Antalya ilinin seçilmesinin temel nedeni, Türkiye genelinde bulunan 685 adet beş yıldızlı otel işletmesinin yaklaşık \%50'sinin (340) Antalya ilinde faaliyet göstermesidir (KTB, 2017). Bu evren içerisindeki örneklem sayısı ise, otel işletmelerinde yatak ve oda başına düşen işgören sayısının (A ğaoğlu, 1992: 122) Antalya ilinde bulunan beş yıldızlı otel sayısı ile çarpılması sonucu elde edilmiştir. Buna göre Antalya ilinde bulunan 193,550 oda sayısı (KTB, 2016) ile oda başına düşen işgören sayısı $(1,18)$ 'nın çarpımı $(1,18$ x 193,550 = 228,389 ) araştırma evrenini oluşturmaktadır. $\mathrm{Bu}$ evren içerisinde \%10 hata payıyla 162 kişi örneklem olarak kabul edilmiştir (Gürbüz ve Şahin, 2014: 130). Bu doğrultuda seçkisiz olmayan örnekleme yöntemlerinden kolayda örnekleme yöntemi ile yüz yüze anket çalışması uygulanmıştır. İmkânlar dâhilinde 350 katılımcıya ulaşılmış; eksiz doldurulan 223 anket değerlendirmeye alınmıştır.

\subsection{Araştırmanın Veri Toplama Araçları}

Araştırmada çalışma yaşam kalitesini ölçmek amacıyla Sirgy vd., (2001) tarafından geliştirilen ve Türkiye'de Küçükusta (2007) ve Afşar (2011) tarafindan kullanılan ölçekten yararlanılmıştır. Küçükusta (2007) tarafından gerçekleştirilen araştırmada ölçeğin genel güvenirlik değeri ,857 bulunmuştur. 16 ifadenin yer aldığ1 ölçek, düşük seviyeli ihtiyaçlar ve yüksek seviyeli ihtiyaçlar şeklinde iki farklı kategori altındaki 7 boyuttan oluşmaktadır. Sağlık ve güvenlik ihtiyaçları tatminini ile ekonomik ve ailevi ihtiyaçların tatminini düşük seviyeli ihtiyaçları oluştururken; sosyal ihtiyaçların tatminini, saygı ihtiyaçlarının tatminini, kendini gerçekleştirme ihtiyaçlarının tatminini, öğrenme ihtiyaçlarının tatmini ve estetik ihtiyaçların tatmini yüksek seviyeli ihtiyaçları tanımlamaktadır. $\mathrm{Bu}$ araştırma kapsamında elde edilen veriler üzerinde faktör analizi gerçekleştirilmiştir Söz konusu analiz Tablo 1'de yer almaktadır.

Tablo 1: Çalışma Yaşam Kalitesi Ölçeği Faktör Analizi

\begin{tabular}{|c|c|c|c|}
\hline Çalışma Yaşam Kalitesi & $\begin{array}{c}\text { Yetenek ve } \\
\text { Kariyer Gelişimi } \\
\text { Tatmini }\end{array}$ & $\begin{array}{c}\text { Sosyal/ } \\
\text { Ekono } \\
\text { mik ve } \\
\text { Aile } \\
\text { İhtiyaçl } \\
\text { arının } \\
\text { Tatmini } \\
\end{array}$ & $\begin{array}{c}\text { Sağlık ve } \\
\text { Güvenlik } \\
\text { İhtiyaçlarının } \\
\text { Tatmini }\end{array}$ \\
\hline 15. İşimin yaratıcılık içeren yönleri vardır. &, 808 & & \\
\hline 14. İşim mesleki becerilerimi güçlendirmeye olanak sağlar. & ,806 & & \\
\hline $\begin{array}{l}\text { 13. Sürekli olarak işimi daha iyi yapmama yardımcı olacak yeni şeyler } \\
\text { öğrenebiliyorum. }\end{array}$ & ,775 & & \\
\hline 16. İşim, iş dışında da yaratıcılığımı geliştirmeme yardımcı olur. &, 675 & & \\
\hline $\begin{array}{l}\text { 12. Kendi iş kolumda bir uzman olarak potansiyelimi gerçekleştirmekte } \\
\text { olduğumu düşünüyorum. }\end{array}$ &, 572 & & \\
\hline $\begin{array}{l}\text { 11. İşimin bütün potansiyelimi gerçekleştirmeme olanak sağladığını } \\
\text { düşünüyorum. }\end{array}$ &, 509 & & \\
\hline 8. İşiniz dışında yaşamdaki diğer şeylere ayıracak yeterli zamanı bulabiliyorum. & & ,754 & \\
\hline 5. Bu işyerindeki işimin yaşam boyunca garanti altında olduğunu düşünüyorum. & &, 745 & \\
\hline 6. İşim ailem için iyi olanaklar sunar. & &, 664 & \\
\hline 4.Yaptığınız işin karşılığında aldığım ücretten memnunum. & &, 518 & \\
\hline 2. İşim bana sağlik güvencesi sağlar. & & &, 757 \\
\hline 1. Kendimi işyerinde fiziksel olarak güvende hissederim. & & & ,692 \\
\hline 3. Sağlıklı ve zinde kalmak için elimden geleni yaparım. & & & ,463 \\
\hline Boyutların Varyansı Açıklama Yüzdesi & 23,954 & 18,795 & 16,078 \\
\hline Açıklanan Toplam Varyans & & $\mathbf{5 8 , 8 2 7}$ & \\
\hline Kaiser-Meyer-Olkin & &, 831 & \\
\hline Barlett & & $\mathbf{1 0 2 9 , 5 7 8}$ & \\
\hline Boyutların Güvenilirlik Değerleri & ,722 & ,724 &, 605 \\
\hline Genel Güvenilirlik & & ,849 & \\
\hline
\end{tabular}

Tablo 1'de yer alan analiz sonucunda ölçeğin, üç boyutlu bir yapıya sahip olduğu görülmektedir (Kaiser-MeyerOlkin: ,849). Faktör yükü düşük olduğu için üç ifade ölçekten çıkarılmıştır. Sağlık ve güvenlik ihtiyaçları tatmini (açıklanan varyans $=16,078 /$ cronbach's alpha $=, 605$ ) orijinal çalışma ile benzerlik gösterirken, diğer boyutlar bu çalışmada farklı bulgulanmıştır. Ayrıca sağlık ve güvenlik ihtiyaçlarına ilişkin elde edilen cronbach's alpha katsayısının değerlendirilmesinde $0,00 \leq \alpha<0,60$ aralığındaki değerlerin güvenilir olduğu (Kalaycı vd., 2010: 405) dikkate alınmıştır. Sosyal ihtiyaçların tatmini boyutundan bir ifade ekonomik ve ailevi ihtiyaçların tatminini boyutunda yer almıştır. İfadelerin benzer anlamlara sahip olması nedeniyle boyut tablodaki haliyle adlandırılmıştır (açıklanan varyans $=18,795 /$ cronbach's alpha $=, 724)$. Son olarak kendini gerçekleştirme ve öğrenme ihtiyaçları ile 
estetik ihtiyaçların tatmini boyutlarındaki ifadelerin aynı faktör boyutunda yer aldığı görülmüştür. Faktör yükleri, açıklanan varyans $(23,954)$, güvenirlik düzeyi $(0,841)$ ve ifadelerin anlam bütünlüğü dikkate alındığında ulaşılan bu sonucun uygun olduğuna karar verilmiş ve tablodaki haliyle adlandırılmıştır. Nitekim üç boyuttan oluşan ölçeğin genel güvenirlik değeri 0,849'dur. Ayrıca her boyut için normallik testi uygulanmış, Skewness ve Kurtosis değerlerinin $-1,000$ ile $+1,000$ uyum aralığında olduğu tespit edilmiştir (Hair vd., 2013). Örgütsel sinizm algısını ölçmek amaciyla Brandes'in (1997) geliştirmiş olduğu, üç boyut ve 14 ifadeden oluşan örgütsel sinizm ölçeği kullanılmıştır. Ölçeğin Türkçeye uyarlama çalışması Erdost vd., (2007) tarafindan gerçekleştirilmiştir. Söz konusu ölçek duyuşsal sinizm $(\alpha=, 864)$, davranışsal sinizm $(\alpha=, 719)$ ve bilişsel sinizm $(\alpha=, 912)$ olmak üzere üç boyuta ayrılmaktadır. Örgütsel sinizm ölçeğiyle ilgili bu araştırma kapsamında elde edilen veriler Tablo 2'de yer almaktadır.

Tablo 2: Örgütsel Sinizm Ölçeği Faktör Analizi

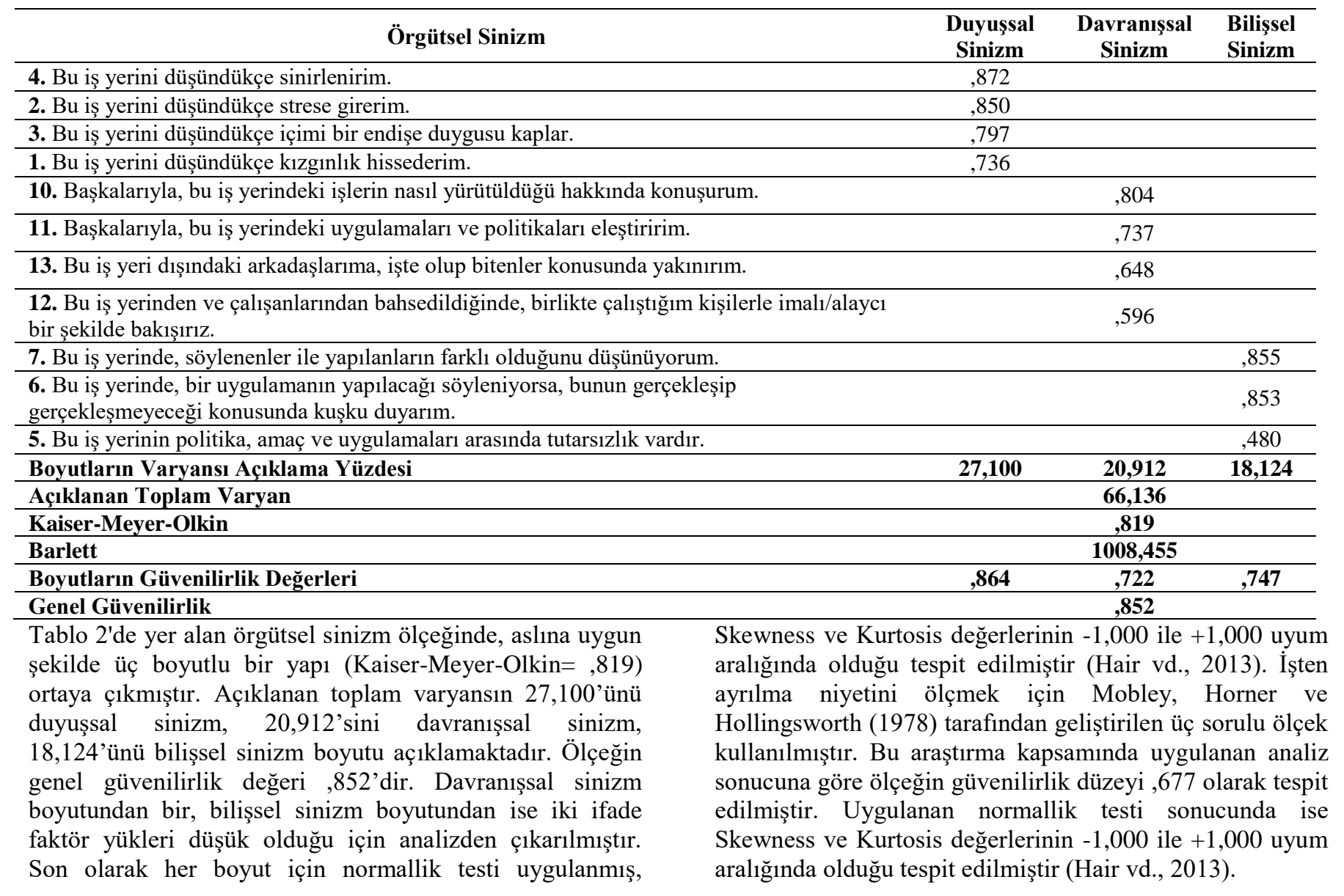

Tablo 3: İşten Ayrılma Niyeti Faktör Analizi

\begin{tabular}{lll}
\hline 1. Çoğu kez mevcut işimi bırakmayı düşünüyorum. &, 809 \\
\hline 2. Aktif bir şekilde başka şirketlerde iş arıyorum. &, 805 \\
\hline 3. İşimden muhtemelen yakın bir zamanda ayrıclacăım. &, 723 \\
\hline Açılanan Toplam Varyans= 60,790 $\quad$ Kaiser-Meyer-Olkin=,650 & Barlett= 105,705 & Güvenilirlik=,,677 \\
\hline
\end{tabular}

\section{Bulgular}

\subsection{Demografik Bulgular}

Araştırmaya 88 kadın 135 erkek katılım göstermiştir. Katılımciların 119'u 18-23, 52'si 24-29 ve 52'si 30 üzeri yaş aralığındadır. Ayrıca katılımcıların çoğunluğu ortaöğretim, ön lisans ve lisans mezunudur $(\% 77,1)$. Turizm sektöründeki çalışma süresi incelendiğinde 117 kişinin 1 yıldan az, 33 kişinin 1-3 yıl ve 52 kişinin 4-6 yıl aralığında sektörel tecrübeye sahip olduğu tespit edilmiştir. Çalışılan oteldeki kadro durumu incelendiğinde, katılımcıların çoğunluğunun sezonluk faaliyet gösterdiği görülmektedir (\%91,5). Bu durumun Antalya ilindeki otellerin genelinin sezonluk hizmet veriyor olmasından kaynaklandığı düşünülmektedir. Ayrıca katılımcıların \%80,3'ü işgören, $\% 16,1$ 'i şef ve $\% 3,6$ 's1 departman müdüründen oluşmaktadır. Son olarak katılımcılar departman bağlamında incelendiğinde çoğunluğun ön büro, yiyecek içecek ve kat hizmetlerinde çalıştığ 1 tespit edilmiştir $(\% 72,7)$.

\subsection{Araştırma Değişkenlerine İlişkin Korelasyon Analizi Sonuçları}

Çalışma yaşam kalitesi, örgütsel sinizm ve İAN'nin ortalama değerleri ve standart sapmaları tespit edilmiş, ardından korelasyon analizi gerçekleştirilmiştir. Sonuçlar Tablo 4'te yer almaktadır. Çalışma yaşam kalitesinin yetenek ve kariyer gelişimi ile sağlık ve güvenlik ihtiyaçlarının tatmini boyutu orta düzeyde tespit edilmiştir. 
Sosyal/ekonomik ve aile ihtiyaçlarının tatmini boyutu ise düşük düzeyde belirlenmiştir. Örgütsel sinizmin üç boyutu ile işten ayrılma niyeti ise düşük düzeyde bulgulanmıştır.

Tablo 4: Korelasyon Analizi Sonuçları

\begin{tabular}{|c|c|c|c|c|c|c|c|c|c|}
\hline Boyutlar & Ort. & s.s. & 1 & 2 & 3 & 4 & 5 & 6 & 7 \\
\hline 1. Yetenek ve Kariyer Gelişimi Tatmini & 3,265 & ,916 & 1 & & & & & & \\
\hline 2. Sosyal/ Ekonomik ve Aile İhtiyaçlarının Tatmini & 2,392 & 990 &, $436^{* *}$ & 1 & & & & & \\
\hline 3. Sağlık ve Güvenlik İhtiyaçlarının Tatmini & 3,590 & 929 &, $437^{* *}$ &, $462^{* *}$ & 1 & & & & \\
\hline 4. Duyuşsal Sinizm & 2,612 & 1,158 &,$- 145^{*}$ &,$- 246^{* *}$ &,$- 206^{* *}$ & 1 & & & \\
\hline 5. Bilişsel Sinizm & 2,626 & 1,078 &,$- 262^{* *}$ &,$- 358^{* *}$ &,$- 244^{* *}$ &, $440^{* *}$ & 1 & & \\
\hline 6. Davranışsal Sinizm & 2,669 & 1,058 &,$- 227^{* *}$ &,$- 368^{* *}$ &,$- 368^{* *}$ &, $423^{* *}$ &, $490^{* *}$ & 1 & \\
\hline 7. İşten Ayrılma Niyeti & 2,509 & 1,098 &,$- 260^{* *}$ &,$- 254^{* *}$ &,- 099 &, $387^{* *}$ &, $383^{* *}$ &, $261^{* *}$ & 1 \\
\hline
\end{tabular}

Çalışma yaşam kalitesinin üç boyutu ile örgütsel sinizm boyutlarının -,368 ile -,145 arasında farklılaşan anlamlı ve ters yönlü ilişki değerlerine sahip olduğu görülmüştür. En yüksek ilişki, sosyal/ekonomik ve aile ihtiyaçları ile sağlık ve güvenlik ihtiyaçlarının tatmini boyutları ile davranışsal sinizm boyutu arasında olduğu görülmektedir. Benzer şekilde çalışma yaşam kalitesi boyutları ile işten ayrılma niyeti arasında da -,260/-,099 arasında değişen, ters yönlü ilişki olduğu belirlenmiştir. Ancak sağlık ve güvenlik ihtiyaçlarının tatmini ile işten ayrılma niyeti arasında anlamlı bir ilişkinin olmadığı görülmüştür. Son olarak, örgütsel sinizm boyutları ile işten ayrılma niyeti arasında anlamlı ve doğru yönlü ilişki olduğu belirlenmiştir. Ulaşılan bu sonuçlar çerçevesinde, Çalışma yaşam kalitesi ile örgütsel sinizm ve işten ayrılma niyeti arasında anlamlı ve kuramsal varsayımlarla örtüşen ilişki örüntülerinin olduğunu söylemek mümkündür.

\subsection{Regresyon Analizi Sonuçları}

Araştırma hipotezlerini test amacıyla dört farklı regresyon modeli test edilmiştir. Model 1'deki regresyon analizi sonuçlarına göre çalışma yaşam kalitesi örgütsel sinizmin yaklaşık \%16'sını $\left(\mathrm{r}=, 403 / \mathrm{r}^{2}=, 162 / \mathrm{p}=0,000\right)$ anlamlı şekilde açıklamaktadır. Standardize edilmiş beta katsayına göre, çalışma yaşam kalitesinin örgütsel sinizm üzerindeki etkisinin ters yönde $(\beta=-, 468)$ olduğu görülmektedir. Buna göre, çalışma yaşam kalitesindeki olası düşüş, çalışanların örgütsel sinizm tutumlarını yükseltmektedir. Bu sonuçla, araştırmanın birinci hipotezi kabul edilmiş, ayrıca aracılık testinin "bağımsız değişken aracı değişken üzerinde anlaml bir etkiye sahiptir" koşulu (Baron ve Kenny, 1986) sağlanmıştır. İkinci modelde çalışma yaşam kalitesinin işten ayrılma niyeti üzerindeki etkisi test edilmiştir. Model işten ayrılma niyetinin yaklaşık \% $\%$ 'sini $\left(\mathrm{r}=, 276 / \mathrm{r}^{2}=, 076 / \mathrm{p}=, 000\right)$ açıklamaktadır. Çalışma yaşam kalitesinin işten ayrılma niyeti üzerindeki etkisinin, örgütsel sinizmde olduğu gibi, ters yönlü $(\beta=-, 402)$ olduğu belirlenmiştir. Buna göre, çalışma yaşam kalitesine ilişkin işgören algılarındaki düşüş, işten ayrılma niyetinin ortaya çıkmasına yol açmaktadır. Bu sonuçla, araştırmanın ikinci hipotezi kabul edilmiş ve aracılık testi için öne sürülen ikinci koşul (Baron ve Kenny, 1986) da sağlanmıştır. Üçüncü regresyon modelindeki sonuçlara göre, olası aracı değişken örgütsel sinizm, işten ayrılma niyetinin yaklaşık \%18'ini açıklamaktadır $\left(\mathrm{r}=, 429 / \mathrm{r}^{2}=, 184 / \mathrm{p}=, 000\right)$. Ayrica örgütsel sinizmin işten ayrılma niyeti üzerindeki etkisinin doğru yönlü olduğu görülmüştür $(\beta=, 537)$. Bu sonuçla aracılık testinin üçüncü koşulu (Baron ve Kenny, 1986) sağlanmış ve araştırmanın üçüncü hipotezi desteklenmiştir. Model 4'te çoklu regresyon analizi sonuçları yer almaktır. Test sonuçlarına göre, çalışma yaşam kalitesi işten ayrılma niyeti üzerindeki anlamlı etkisini $(\beta=-, 180 / p=, 062)$ örgütsel sinizm modele dâhil edildiğinde kaybetmektedir. Model işten ayrılma niyetinin yaklaşık \%19'unu açıklamaktadır. Standardize edilmiş beta katsayılarına göre örgütsel sinizmin modele katkısı ,474 düzeyindedir. Çalışma yaşam kalitesinin, örgütsel sinizmin modele dâhil edilmesiyle etkisini yitirmesi ve Sobel testi sonuçları dikkate alındığında, örgütsel sinizmin çalışma yaşam kalitesinin işten ayrılma niyeti üzerindeki etkisinde tam aracı değişken olduğu sonucuna ulaşılmıştır. Böylelikle araştırmanın dördüncü hipotezi kabul edilmiştir. Sonuçlar Tablo 5'te yer almaktadır

Tablo 5: Regresyon Analizi Sonuçları

\begin{tabular}{|c|c|c|c|c|c|c|c|}
\hline Bağımsız Değişkenler & Bağımlı Değişkenler & $\mathbf{B}$ & $\mathbf{t}$ & $\mathbf{p}$ & $\mathbf{r}$ & $\mathbf{r 2}$ & $\mathbf{F} / \mathbf{p}$ \\
\hline \multicolumn{2}{|c|}{ Model 1} & & 18,009 & 000 & \multirow{2}{*}{,403 } & \multirow{2}{*}{, 162} & \multirow{2}{*}{$42,779 /, 000$} \\
\hline H1. Çalışma Yaşam Kalitesi & Örgütsel Sinizm &,- 468 & $-6,541$ & 000 & & & \\
\hline \multicolumn{2}{|c|}{ Model 2} & & 12,588 &, 000 & \multirow{2}{*}{, 276} & \multirow{2}{*}{,076 } & \multirow{2}{*}{$18,280 /, 000$} \\
\hline H2. Çalışma Yaşam Kalitesi & İşten Ayrılma Niyeti &,- 402 & $-4,276$ & 000 & & & \\
\hline \multicolumn{2}{|c|}{ Model 3} & & 5,173 &, 000 & \multirow[b]{2}{*}{,429 } & \multirow{2}{*}{, 184} & \multirow{2}{*}{$49,732 /, 000$} \\
\hline H3. Örgütsel Sinizm & İşten Ayrılma Niyeti & 537 & 7,052 & 000 & & & \\
\hline \multicolumn{2}{|c|}{ Model 4 Aracilık Testi } & & 4,149 & ,000 & \multirow{3}{*}{,443 } & \multirow{3}{*}{, 197} & \multirow{3}{*}{$26,910 /, 000$} \\
\hline \multirow{2}{*}{ H4. $\frac{\text { Çalışma Yaşam Kalitesi }}{\text { Örgütsel Sinizm }}$} & \multirow{2}{*}{ İşten Ayrılma Niyeti } &,- 180 & $-1,877$ &, 062 & & & \\
\hline & &, 474 & 5,736 & ,000 & & & \\
\hline & & $=-4.2$ & $=, 000$ & & & & \\
\hline
\end{tabular}

$\mathrm{p}<0.05^{*}, \mathrm{p}<0.01 * *$ ve $\mathrm{p}<0.001 * * *$

\section{Sonuç}

$\mathrm{Bu}$ araştırma çalışma yaşam kalitesinin işten ayrılma niyeti üzerindeki etkisini ve bu olası etkinin ortaya çıkmasında örgütsel sinizmin aracılık rolünü tespit etmek amacıyla gerçekleştirilmiştir. Araştırma sonuçlarına göre; otel çalışanlarındaki örgütsel sinizm algısı ve işten ayrılma niyetinin düşük düzeyde olduğu, çalışma yaşam kalitesinin 
ise orta düzeyde olduğu bulgulanmıştır. Elde edilen bu sonuç; otel çalışanlarının işten ayrılma niyetinin azaltılması, sinik tutumların oluşmadan engellenmesi ve çalışma yaşam kalitesinin iyileştirilmesi bakımından önem taşımaktadır. $\mathrm{Bu}$ önem doğrultusunda literatür incelendiğinde benzer kimi araştırma sonuçlarına da rastlanmaktadır. Örneğin; otel çalışanlarındaki işe yabancılaşma ve örgütsel sinizm arasındaki ilişkinin incelendiği bir araştırmada, söz konusu kavramlar arasında pozitif yönlü ve anlamlı ilişki olduğu tespit edilmiştir (Demir vd., 2018). Bir başka çalışmada ise, otel çalışanlardaki sinizm algısı arttıkça işe yabancılaşmanın da artacağı vurgulanmıştır (Özer ve Güllüce, 2019). İşe yabancılaşmanın yanı sıra sinizmin tükenmişlik üzerinde etkisinin olduğu da bilinmektedir. Örneğin yapılan bir araştırmada otel çalışanlarındaki sinik tutum ya da algıların tükenmişliği arttırdığı ifade edilmektedir (İbrahimağaoğlu ve Can, 2017). Dolayısıyla bu araştırma kapsamında elde edilen bulguların benzer araştırma sonuçlarıyla da desteklendiğini ifade etmek mümkündür. Araştırma hipotezlerinin test edilmesi amacıyla gerçekleştirilen regresyon analizi sonucunda ise, çalışma yaşam kalitesinin örgütsel sinizm ve işten ayrılma niyeti üzerinde anlamlı ve negatif yönlü bir etkisinin olduğu görülmüştür. Bu durum otel çalışanlarındaki çalışma yaşam kalitesi azaldıkça örgütsel sinizm ve işten ayrılma niyetinin artacağ 1 şeklinde yorumlanabilmektedir. Başka bir deyişle çalışanların düşük çalışma yaşam kalitesi, sinik tutum ve algıları arttırmakta ve işten ayrılma ile sonuçlanmaktadır. Bu kapsamda literatür incelendiğinde, düşük çalışma yaşam kalitesinin sinizm üzerindeki etkisinin yanı sıra örgütsel bağl1lık üzerindeki negatif etkisine yönelik bazı çalışmaların bulunduğu görülmektedir (Ayden ve Gündoğdu, 2020; Işık ve Başar, 2019). Buradan hareketle otel işletmelerinde çalışma yaşam kalitesinin sağlanmasının, bireylerin sinik tutumlarında, örgütsel bağlılıkta ve işten ayrılma niyetinde belirleyici bir etkiye sahip olduğu ifade edilebilir. Aksi durumda çalışanların duygu durumları olumsuz etkilenmekte, işyerinde güvensizlik, şüphe, şikâyet, eleştiri, alay gibi tutumların sergilenmesine yol açabilmekte ve nihayetinde işten ayrılma niyetini ortaya çıkarabilmektedir. Son olarak çalışma yaşam kalitesinin işten ayrılma niyeti üzerindeki etkisinde örgütsel sinizmin aracıllk etkisinin olup olmadığına yönelik gerçekleştirilen analiz sonucunda; örgütsel sinizmin tam aracılık rolüne sahip olduğu görülmüştür. $\mathrm{Bu}$ sonuç, çalışma yaşam kalitesine yönelik olumsuz algıların öncelikle örgütsel sinizm tutumlarına yol açtığını ve sonrasında işten ayrılma niyetini doğurduğunu işaret etmektedir. Bu bağlamda önemli bir sorun; işten ayrılma niyetinde olan ama halen çalışmaya devam eden otel çalışanının sinik davranışlar sergileyen diğer çalışanlar üzerinde nasıl bir etkiye sahip olduğudur. Keza sinik tutumlar; sürekli şikâyet, eleştiri, alay gibi davranışlara yol açarken (Barefoot vd., 1989: 48; Cook ve Medley 1954: 414), örgütsel iklimi, çalışma kültürünü, işyerindeki birlikberaberlik duygusunu olumsuz etkileyebileceği gibi sonuçta farklı sorunları getirebilecektir. Bu bakımdan sonraki çalışmalarda, her üç değişken arasındaki ilişkinin örtük neden, süreç ve sonuçlarını anlamak ve çalışma yaşam kalitesi algısı düşük ama örgütsel sinizm tutumları göstermeyen ve işten ayrılmayı da düşünmeyen çalışanların bu durumla nasıl baş ettiklerini anlamak için derinlemesine görüşmelerle nitel araştırmalar gerçekleştirilebilir.

\section{Kaynakça}

Abraham, R. (2000). Organizational Cynicism: Bases And Consequences Genetic. Social, and General Psychology Monographs, 126(3), 269-292.

Afşar, S. T. (2011). Çalışma Yaşam Kalitesinin Örgütsel Bağlllık Düzeyi Üzerindeki Etkisi: Devlet ve Vakıf Üniversitelerinde Çalışan Akademisyenler Üzerine Nicel Bir Araştırma. Doktora Tezi. Ankara: Hacettepe Üniversitesi.

Ağaoğlu, O. K. (1992). Işsücünü Verimli Kullanma Tekniklerinin Turizm Sektörüne Uygulanması. Ankara: Milli Prodüktivite Merkezi.

Akman, Y. \& Akman, G. İ. (2017). İlköğretim Okulu Öğretmenlerinin Çalışma Yaşam Kalitesi Algısının İşle Bütünleşmeleri Üzerindeki Etkisi. Illkögretim Online, 16(4), 1491-1504

Akman, G. (2013). Sağlık Çalışanlarının Örgütsel ve Genel Sinizm Düzeylerinin Hastane ve Sağlık Kuruluşlarında Karşılaştırllması. Yüksek Lisans Tezi. İstanbul Üniversitesi.

Alan, H. (2012). Hemşirelerde Çalışma yaşam Kalitesi Ölçeği Geliştirme: Bir Uygulama, Yüksek Lisans Tezi. İstanbul: Haliç Üniversitesi.

Andersson, L. M. \& Bateman, T. S. (1997). Cynicism in The Workplace: Some Causes and Effects. Journal of Organizational Behavior, 18(5), 449-469.

Avc1, N. \& Küçükusta, D. (2009). Konaklama İşletmelerinde Örgütsel Öğrenme, Örgütsel Bağlılık ve İşten Ayrılma Eğilimi Arasındaki İlişki. Anatolia: Turizm Araştırmaları Dergisi, 20(1), 33-44.

Ayden, C. \& Gündoğdu, G. İşgörenlerin Çalışma Yaşam Kalitesi Algısı ve Örgütsel Bağlılık İlişkisi: Elazı̆̆ İli Sağlık Çalışanları Örnek Uygulaması. Fırat Üniversitesi Sosyal Bilimler Dergisi 30(1). 177-197.

Baron, R. M. \& Kenny, D. A. (1986). The ModeratorMediator Variable Distinction in Social Psychological Research: Conceptual, Strategic, and Statistical Considerations. Journal of Personality and Social Psychology, 51(6), 1173-1182.

Barefoot, J. C., Dodge, K. A., Peterson, B. L., Dahlstrom, W. G., \& Williams, R. B. (1989). The Cook-Medley Hostility Scale: Item Content and Ability to Predict Survival. Psychosomatic Medicine, 51(1), 46-57.

Blau, P. M. (1964). Exchange and Power in Social Life. New Jersey: Transaction Publishers.

Bouckenooghe, D., Raja, U. \& Butt, A. N. (2013). Combined Effects of Positive and Negative Affectivity and Job Satisfaction On Job Performance and Turnover İntentions. The Journal of psychology, 147(2), 105-123.

Brandes, P. (1997). Organizational Cynicism: Its Nature, Antecedents and Consequences. Dissertation of Doctor of Philosophy, University of Cincinnati. Ohio. 
Brandes, P. \& Das, D. (2006). Locating Behavioral Cynicism at Work: Construct Issues and Performance Implications in Employee Health, Coping and Methodologies. Emerald Group Publishing Limited, (5), 233-266.

Cabrera, E. F. \& Cabrera, A. (2005). Fostering Knowledge Sharing Through People Management Practices. The International Journal Of Human Resource Management, 16(5), 720-735.

Cotton, J. L. \& Tuttle, J. M. (1986). Employee Turnover: a Meta-Analysis and Review with Implications for Research. Academy of Management Review, 11(1), 5570.

Cook, W. W., \& Medley, D. M. (1954). Proposed Hostility and Pharisaic-Virtue Scales for the Mmp1. Journal of Applied Psychology, 38(6), 414-418.

Cropanzano, R. \& Mitchell, M. S. (2005). Social Exchange Theory: an Interdisciplinary Review. Journal of Management, 31(6), 874-900.

Çelik, İ. Y. \& Uğurluoğlu, Ö. (2011). Sağlık Personeli Çalışma Yaşam Kalitesi Ölçeği: Geliştirilmesi, Geçerliliği ve Güvenilirliği. Toplum ve Sosyal Hizmet, 22(2), 79-100.

Çiftçi, D. Ö., Meriç, E., \& Meriç, A. (2015). Örgütsel Sessizlik, Tükenmişlik ve İşten Ayrılma Niyeti İlişkisi: Ordu İli Özel Eğitim ve Rehabilitasyon Merkezlerinde Bir Uygulama. The Journal of International Social Research, 8(41), 996-1007.

Demir, M., Ayas, S., \& Yıldız, B. (2018). Örgütsel Sinizm ve İşe Yabancılaşma İlişkisi: Beş Yıldızlı Otel Çalışanları Üzerine Bir Araştırma. Çanakkale Onsekiz Mart Üniversitesi Yönetim Bilimleri Dergisi, 16(32), 231.

Dean, J. W., Brandes, P. \& Dharwadkar, R. (1998). Organizational Cynicism. Academy of Management Review, 23(2), 341-352.

Donalson, S.(2000). Health Behavior: Quality of Work Life, and Organizational Effectivness in the Lunbe Industry SAGE publication: California.

Eaton, J. A. (2000). A Social Motivation Approach to Organizational Cynicism. Graduate Program in Psychology Unpublished Doctoral Dissertation York University, Toronto.

Elizur, D. (1991). Work and Non Work Relations: The Conical Structure of Work and Home Life Relationship. Journal of Organizational Behavior, 12(4), 313-322.

Emerson, R. M. (1976). Social Exchange Theory. Annual Review of Sociology, 2(1), 335-362.

Erdost, E., Karacaoğlu, K. \& Reyhanoğlu, M. (2007). Örgütsel Sinizm Kavramı ve İlgili Ölçeklerin Türkiye'deki Bir Firmada Test Edilmesi. 15. Ulusal Yönetim ve Organizasyon Kongresi'nde Sunulmuş Bildiri, Sakarya Üniversitesi, Sakarya.
Erdoğan, İ. (2007). Pozitivist Metodoloji: Bilimsel Araştırma Tasarımı, Istatiksel Yöntemler, Analiz ve Yorum. İstanbul: Erk Yayınları.

Feizi, M., D., M., \& Alipour, H. (2013). Surveying the Relationship Between Quality of Work Life Components and Counter Productive Behavior in Ardabil Province of Mellat Bank Employees. Nigerian Chapter of Arabian Journal of Business and Management Review, 62(1087), 1-7.

Fishbein, M. \& Ajzen, I. (1977). Attitude Behavior Relations: A Theoretical Analysis and Review of Empirical Research. Psychological Bulletin, 84(5), 888918.

George, J. M. \& Brief, A. P. (1990). The Economic Instrumentality of Work: An Examination of the Moderating Effects of Financial Requirements and Sex on the Pay-Life Satisfaction Relationship. Journal of Vocational Behavior, 37(3), 357-368.

Görmen, M. (2012). Örgüt Kültürünün Örgütsel Sinizm Üzerindeki Etkisi ve Bir Uygulama, Doktora Tezi. Ankara: Gazi Üniversitesi.

Gürbüz, S. \& Şahin, F. (2014). Sosyal Bilimlerde Araştırma Yöntemleri. Ankara: Seçkin Yayıncılık.

Hair, J. F., Ringle, C. M., \& Sarstedt, M. (2013). Partial Least Squares Structural Equation Modeling: Rigorous Applications, Better Results and Higher Acceptance. Long Range Planning, 46(2), 1-12.

Hardy C. C. (1987). The Blue Chip Investment Strategy: Quality, Value and Timing for Income Appreciation. New York: F Watts.

Homans, G. C. (1961). Human Behavior: Its Elementary Forms, New York: Harcourt Brace \& World.

Işık, M. F. \& Başar, M. S. (2019). İş Yaşam Kalitesinin İşten Ayrılma Niyeti Üzerindeki Rolü: Erzurum İli Palandöken Kış Turizmi Merkezindeki Çalışanlar Üzerinde Bir Uygulama. Journal of International Social Research, 12(66), 1074-1085.

İbrahimağaoğlu, Ö. \& Can, E. (2017). Örgütsel Sinizm ile Örgütsel Tükenmişlik Arasındaki İlişkinin İncelenmesi: Hizmet Sektörü Çalışanları Üzerine Ampirik Bir Araştırma. Yıldız Sosyal Bilimler Enstitüsü Dergisi, 1(2), 181-205.

James, M. S. (2005). Antecedents and Consequences of Cynicism in Organizations: An Examination of The Potential Positive and Negative Effects on School Systems. Doctoral Dissertation, Florida State University, Florida.

Johnson, J. L. \& O'Leary-Kelly, A. M. (2003). The Effects of Psychological Contract Breach and Organizational Cynicism: not allsocial exchange violationsare created equal. Journal of Organizational Behavior, 24(5), 627647. 
Judge, T. A. \& Watanabe, S. (1994). Individual Differences in the Nature of There Lationship Between Job and Life Satisfaction. Journal of Occupational and Organizational Psychology, 67(2), 101-107.

Jung Choi, H. \& Tae Kim, Y. (2012). Work-Family Conflict, Work-Family Facilitation, and Job Outcomes in the Korean Hotel Industry. International Journal of Contemporary Hospitality Management. 24(7), 10111028.

Kalayc1, Ş. (2010). SPSS uygulamalı çok değişkenli istatistik teknikleri(5. Baskl). Ankara: Asil Yayın Dağıtım.

Kheirandish, S.M. (2009). Relation between working life quality and performance of employees in Irank hodro dizeli company. Master's thesis. Alame Tabatabaii University, İran.

Kim, N. (2014). Employee Turnover Intention Among New Comers in Travel Industry. International Journal of Tourism Research.16(1), 56-64.

KTB. (2016). T.C. Kültür ve Turizm Bakanlığı Yatırım ve İşletmeler Genel Müdürlüğü 2016 Yılı İşletme Belgeli Konaklama Tesislerine Giriş ve Geceleme Sayıları. (erişim tarihi: 06.02.2019). http://yigm.kulturturizm.gov.tr/TR,9857/isletme belgelitesisler.

KTB. (2017). T.C. Kültür ve Turizm Bakanlığı Yatırım ve İşletmeler Genel Müdürlüğü 2016 Yılı İşletme Belgeli Konaklama Tesislerine Giriş ve Geceleme Sayıları. (erişim tarihi: 02.06.2017). http://yigm.kulturturizm.gov.tr/TR,9579/turizm-tesisleri

Küçükusta, D. (2007). Konaklama İşletmelerinde Işs-Yaşam Dengesinin Çalışma Yaşam Kalitesi Üzerindeki Etkisi. Doktora Tezi. İzmir: Dokuz Eylül Üniversitesi.

Lokanadha R. M. \& Mohan R. P. (2013). Quality of Work Life of Employees: Emerging Dimensions. Asian Journal of Management Research, 2(2), 827-839.

Martel, J. P. \& Dupuis, G. (2006). Quality of Work Life: Theoretical and Methodological Problems, and Presentation of a New Model and Measuring Instrument. Social indicators research, 77(2), 333-368.

Mayfield, J. \& Mayfield, M. (2007). The Creative Environment's Influence on Intent to Turnover: a Structural Equation Model and Analysis. Management Research News, 31(1), 41-56.

Markham, L. G. (2009). Quality of Work Life as Predictor of Employees' Mental Health. Doctoral Dissertation, University of the Free State, South African.

Mert, G. \& Yılmaz, G. (2019). Beş Yıldızlı Otellerde Örgütsel Sinizmin İşletme Performansına Etkisinde Motivasyon Rolünün İncelenmesi. Electronic Turkish Studies, 14(2), 629-650.
Mirvis, P. H. \& Kanter, D. L. (1991). Beyond Demography: a Psychographic Profile of the Work Force. Human Resource Management, 30(1), 45-68.

Mishra, A. K. \& Spreitzer, G. M. (1998). Explaining How Survivors Respond to Downsizing: the Roles of Trust, Empowerment, Justice, and Work Redesign. Academy of Management Review, 23(3), 567-588.

Morton, H. C. (1977). A Look at Factors Affecting the Quality of Working Life. Monthly Labor Review, 100(10), 64-65.

Mobley, W. H., Griffeth, R. W., Hand, H. H., \& Meglino, B. M. (1979). Review and Conceptual Analysis of the Employee Turnover Process. Psychological Bulletin, 86(3), 493-522.

Naus, A. J. A. M. (2007). Organizational Cynicism: on The Nature, Antecedents, and Consequences Of Employee Cynicism Toward the Employing Organization, Doctoral Dissertion, Universiteit Maastricht.

Özer, S. \& Güllüce, A. Ç. (2019). Örgütsel Sinizm ve İşe Yabancılaşma İlişkisi ve Etkisi: TRB1 Bölgesi Otel İşgörenleri Üzerinde Bir Araştırma. Anemon Muş Alparslan Üniversitesi Sosyal Bilimler Dergisi, 7(1), 3747.

Öztürk Ç., D., Meriç, E. \& Meriç, A. (2015). Örgütsel Sessizlik, Tükenmişlik ve İşten Ayrilma Niyeti İlişkisi: Ordu İli Özel Eğitim ve Rehabilitasyon Merkezlerinde Bir Uygulama. Journal of International Social Research, 8(41), 996-1007.

Rose, R. C., Beh, L., Uli, J. \& Idris, K. (2006). Quality of Work Life: Implications of Career Dimensions. Journal of Social Sciences, 2(2), 61-67.

Rusbult, C. E., Farrell, D., Rogers, G. \& Mainous, A. G. (1988). Impact of Exchange Variables on Exit, Voice, Loyalty, and Neglect: an Integrative Model of Responses to Declining Job Satisfaction. Academy of Management Journal, 31(3), 599-627.

Paré, G., Tremblay, M. \& Lalonde, P. (2000). The Measurement and Antecedents of Turnover Intentions Among it Professionals. Measurement, 33(2), 1-38.

Pelit, E. \& Gökçe, Y. (2019). Yöneticiye Duyulan Güven ile Çalışma Yaşam Kalitesinin İşten Ayrılma Niyetine Etkisi: Otel İşletmeleri İşgörenleri Üzerinde Bir Araştırma. Balikesir University Journal of Social Sciences Institute, 22(41), 503-531.

Pfeffer, J. (2004). Competitive Advantage Through People: Unleashing the Power of the Workforce. HBS Press: Boston, MA.

Shapiro-Coyle, J. A. \& Conway, N. (2005). Exchange Relationships: Examining Psychological Contracts and Perceived Organizational Support. Journal of Applied Psychology, 90(4), 774.

Sirgy, M. J., Efraty, D., Siegel, P. \& Lee, D. J. (2001). A New Measure of Quality of Work Life (qwl) Based on 
Need Satisfaction and Spillover Theories. Social Indicators Research, 55(3), 241-302.

Sim, S. C., \& Choi, H. J. (2017). A Research About Quality of Work-Life, Affective Organizational Commitment and Turnover İntention of $\mathrm{Y}$ Generational Chef. Culinary Science and Hospitality Research, 23(2), 169-180.

Sojka, L. (2014). Specification of the Quality of Work Life Characteristics in the Slovak Economic Environment. Sociologia, 46(3), 283-299.

Steel, R. P. \& Ovalle, N. K. (1984). A Review and MetaAnalysis of Research on the Relationship Between Behavior Intentions and Employee Turnover. Journal of Applied Psychology, 69(4), 673.

$\mathrm{Su}, \mathrm{H}$. W. (2014). The Factors of Turnover Intention in Hotel Industry. International Journal of Research and Reviews in Applied Sciences, 21(1), 31-38.

Nanjundeswaraswamy, T. S. \& Swamy, D. R. (2015). An Empirical Research on the Relationship. Bangladesh Sociological Society, 12(1), 41-52.

Tett, R. P. \& Meyer, J. P. (1993). Job Satisfaction, Organizational Commitment, Turnover Intention, and Turnover: Path Analyses Based on Meta-Analytic Findings. Personnel Psychology, 46(2), 259-293.

Tuncer, M. \& Yeşiltaş, M. (2013). Çalışma Yaşam Kalitesinin Otel İşletmesi Çalışanları Üzerindeki Etkileri. İşletme Araştırmaları Dergisi, 5(1), 57-78.

Tuna, M. \& Yeşiltaş, M. (2014). Etik İklim, işe Yabancılaşma ve Örgütsel Özdeşleşmenin İşten Ayrılma Niyeti Üzerindeki Etkisi: Otel İşletmelerinde Bir Araştırma. Anatolia: Turizm Araştırmaları Dergisi, 25(1), 105-117
Turan, S. (2014). Psikolojik Güçlendirme ile Çalışma Yaşam Kalitesi Arasındaki Ilişkinin İncelenmesi: Hizmet Sektörü Çalışanlarl Üzerine Bir Uygulama. Yüksek Lisans Tezi. Gaziantep: Hasan Kalyoncu Üniversitesi.

Üstündağ, N. (1999). Akıllı Binaların Tesis Yönetimi Çalışma Yaşam Kalitesi Üzerindeki Etkiler. Doktora Tezi. İstanbul Üniversitesi

Veenhoven, R. (1996). Happy Life-Expectancy. Social Indicators Research, 39(1), 1-58.

Vroom, V. H. (1964). Work and Motivation. John Wiley and Sons: New York.

Yücel, İ. \& Demirel, Y. (2013). Mevcut İş Alternatiflerinin İş Tatmini ve İşten Ayrılma İlişkisi Üzerine Etkisi: Başka Bir Yol Daha Olmalı!. Atatürk Üniversitesi Ítisadi ve İdari Bilimler Dergisi, 27(2), 159-177.

Yin-Fah, B. C., Foon, Y. S., Chee-Leong, L. \& Osman, S. (2010). An Exploratory Study on Turnover Intention Among Private Sector Employees. International Journal of Business and Management, 5(8), 57.

Waitayangkook, C. (2003). Quality of Work Life: Interactional Perspective With Thai Aspect, University of North Texas: consultant, scri, manplaw office, Bangkook, Thailand.

Walton, R. E. (1975). Quality of Working Life: What is it. Sloan Management Review, 15(1), 11-21.

Zengin, A. A. (2018). Algllanan Liderlik Stilinin Çalışma Yaşam Kalitesi Üzerindeki Etkisi: X ve Y Kuşaklart Arası Karşılaştırma. Yüksek Lisans Tezi. Ankara: Nişantaşı Üniversitesi.

Zopiatis, A., Constanti, P. \& Theocharous, A. L. (2014). Job Involvement, Commitment, Satisfaction and Turnover: Evidence From Hotel Employees in Cyprus. Tourism Management, 41, 129-140. 